\title{
Problems of Turkish education system and suggested solutions: What do pre-service teachers think?
}

\author{
Özge Öztekin Bayır ${ }^{1}$ and Esra Tekel² \\ ${ }^{1}$ Eskişehir Osmangazi University, Faculty of Education, Turkey (ORCID: 0000-0003-3723-206X) \\ ${ }^{2}$ Afyon Kocatepe University, Sandikli School of Applied Sciences, Turkey (ORCID: 0000-0003-4600-9900)
}

\begin{abstract}
The main purpose of this study is to examine and put forward the opinions of pre-service teachers about the problems in the Turkish education system and their solution suggestions. The phenomenological model was used in the qualitatively designed study. The participants of the study are 148 students attending the education faculty of a university in the central Anatolia region in Turkey during the spring term of 2020-2021 academic year. The data of the study were collected through a data collection instrument prepared by the researchers and the participants were asked to fill out the instrument by replying to the questions. According to the analysis, the problems of Turkish education system and solutions suggested for these problems were classified under six themes: (i) knowledge provided at schools, (ii) student characteristics, (iii) teaching profession, (iv) physical environment, (v) society's perception and (vi) implemented policies.
\end{abstract}

Keywords: Turkish education system; Problem; Solution suggestion; Pre-service teacher

Article History: Submitted 11 November 2020; Revised 3 March 2021; Published online 23 March 2021

\section{Introduction}

Education is like the light reflected from the prism of wisdom that connects the past to the present and the present to the future while simultaneously mirroring us.

-Ayhan Aydin, Education Policy

Despite the lack of a commonly agreed definition of education, it is clear that the focus of the available definitions lies on the process of developing individuals. Accordingly, the issues that stand out within the framework of the goals of education process are discovering individuals' inborn talents and improving their personality characteristics; moreover, education is considered as a service for humanity and a lifelong process (Şişman, 2019). Although it is difficult to make a common and immutable definition of education, it is possible to say it basically deals with how life can be improved to develop in a better way.

Education which is defined as "helping children and young people directly or indirectly to acquire necessary knowledge, skills and mentalities and to improve themselves both at school and in out-of-school environments" (Turkish Language Association, n.d.), emphasizes mental,

Address of Corresponding Author

Esra Tekel, PhD, Afyon Kocatepe University, Sandikli School of Applied Sciences, Yunus Emre Campus, 03510, Sandikli/Afyonkarahisar.

$\triangle$ esracakmak88@hotmail.com

How to cite: Öztekin-Bayır, Ö. \& Tekel, E. (2021). Problems of Turkish education system and suggested solutions: What do pre-service teachers think?. Journal of Pedagogical Research, 5(1), 275-292. http://dx.doi.org/10.33902/JPR.2021167894 
emotional, kinetic and social changes in individuals and aims to improve them in all dimensions. Accordingly, all educational activities are planned to achieve certain goals and fulfill the functions serving this purpose. When considered together with different concepts, education has a rich variety of goals and functions. We may categorize these purposes and functions as individual, social, cultural, political and economic (Şişman, 2011).

Individuals constitute the social structure, which is mainly shaped by education. In this sense, education plays an important role in the development of societies and their attempts to maintain their existence (Özdemir \& Kaplan, 2017). Each society has short-term and long-term goals. The education system which shapes the future of individuals and societies, is believed to be one of the basic components that allow societies to achieve these short-term and long-term goals (Demir, 2017). The education system, which emerged with the combination of "education" as a field of social sciences and the concept of the "system", which is defined as a unity based on the elements that are in relationship with each other to accomplish specific objectives can be considered as a social structure (Şişman, 2019).

The education systems started to get varied during the period of modernization. One of the factors leading to this variation is the emergence of nation states, which triggered nationalism and the development of national education systems (Ergün, 2018). Education systems are shaped according to unique characteristics, conditions, expectations and needs of each particular society, which is a significant factor leading to such variety in education systems in relation to countries. Another factor is the differences in individuals to be educated and societies to be formed. Likewise, Turkish national education system changed and is still continuing to evolve due to the effects of educational philosophies reflecting different educational approaches throughout the history of education.

Some national and international legal documents played a determinant role in the formation of the Turkish national education system. It is acknowledged that the current structure is based on the legislative regulation titled Tevhid-i Tedrisat (Unification of Education) and enacted on March 3rd 1924 (Başdemir, 2012; Özdemir \& Topal, 2019). In addition, Basic Law of National Education numbered 1739 and published in 1973 is also considered one of the most important documents regulating our education system. This law lists the basic goals of Turkish national education and its basic principles. These basic principles read as follows: (i) universality and equality, (ii) needs of individuals and society (iii) guidance, (iv) right to education, (v) equality of opportunities and facilities, (vi) sustainability, (vii) Atatürk's revolutions and principles and Atatürk's nationalism (viii) democracy, (ix) secularism, (x) scientificity, (xi) planning, (xii) co-education, (xiii) education campuses and collaboration between school and family and finally (xiv) education everywhere. These goals and principles are the main factors that determine the quality of education. Ulug (1998) states that the basic goal of the Turkish education system is to provide effective and quality education so that society can continue to exist and function properly.

Education has an important role in sustainable development of societies. Therefore, it is essential to organize education systems of countries effectively and productively (Kara, 2020). According to Karip and Köksal (1996), society's changing needs in terms of knowledge require authorities to improve the quality of these systems. Thus, as pointed out by Kaya (2008), education should be seen as a constantly developing organism rather than a stable structure. In this sense, social, legal, political or economic changes inevitably result in a restructuring process in the Turkish education system, during which authorities try to meet the demands of the modern era and provide solutions to existing problems.

Gedikoğlu (2005) claims that Turkish education system has certain problems due to its structure shaped by the previous legislative regulations and its current operations. Similarly, Örücü (2014), in his study, emphasized that the problems of the Turkish education system are increasing in number and becoming more and more complex due to paradigm changes in the field of education. When we examine studies focusing on the problems of the Turkish education system, we can see that the following problems are the most commonly stated ones: instability (Başdemir, 2012; 
Gedikoğlu, 2005; Kara, 2020), quality of teachers (Taşdemir, 2015), understanding of education and educational program (Ural, 2006; Yeşil \& Şahan, 2015), exam-oriented and memorization-based education (Taşdemir, 2015; Yılmaz \& Altınkurt, 2011), inadequate infrastructure and equipment (Kösterelioğlu \& Bayar, 2014), teacher education and employment procedures (Kartal, 2013; Taşdemir, 2015; Yılmaz \& Altınkurt, 2011), access to education (Gül, 2008), guidance (Kutlu-Abu et al., 2016), ideological approach, failure to utilization expert experience, financing (Gür \& Çelik, 2009; Özyılmaz, 2013; Yaşar \& Sözbilir, 2017), vocational and technical education (Yılmaz \& Altınkurt, 2011), problems encountered while educating qualified educational administrators and during school administration processes (Demirtaş et al., 2007; Kösterelioğlu \& Bayar, 2014), 12-year compulsory education (Kara, 2020).

The related literature suggests that existing problems in the education system cannot be discussed independently since they are inevitably interrelated and it is necessary to deal with education through a fragmented approach since it has the potential to affect all sections and fields of society (Açıgenç, 2009). In other words, a problem that occurs in any level of education and changes made to solve this problem might affect all fields of society. It is essential to determine the main problem areas in education systems and overcome the identified deficiencies by obtaining opinions of those who are affected or likely to be affected by existing problems (Neyişci et al., 2020).

In most of the studies focusing on the problems of Turkish education systems, the data were collected from teachers and pre-service teachers. Since pre-service teachers are individuals involved in the system and they are students who will start working as a teacher when they graduate from their departments, it is important to explore how they perceive issues related to education (Örücü, 2014). At this point, teachers' opinions shaped by their observations and experiences during their university education and point of views regarding the problems of the education system and solutions they suggest for these problems are significant to ensure an effective operation and long-term sustainability of the Turkish education system. Under the light of this information, the aim of this study is to examine pre-service teachers' opinions regarding the problems of the Turkish education system and their detailed solutions to these problems.

\section{Method}

\subsection{Research Design}

Qualitative research methods and techniques were used in the design of this study. In this study, which aims to reveal the opinions of pre-service teachers about the problems in the Turkish education system and their solution suggestions, the case study model was used. Case study is an in-depth description and study of a limited system. For example, for a situation to be selected as a case, a certain program or a certain class of students should be examined, or the student should be selected based on criteria such as typicality, contradiction, or success (Merriam, 2009). In this context, the case addressed in this study is the Turkish education system problems.

\subsection{Participants}

The participants have been determined via intensity sampling method, which is a purposive sampling method. Rich information cases manifest the phenomenon of interest intensely in this sampling method (Patton, 2002). According to Patton, before using this sampling method, researchers need to have prior information about whether the participants have the rich information about the phenomenon or not intensely. Therefore, researchers thought that junior students who had just completed their secondary education and passed the university entry exam and senior students who have been studying for Public Personnel Selection Examination (PPSE) have rich information about problems of the Turkish education system. In this regard, 148 preservice teachers from a university in the central Anatolia region in Turkey comprised the sample. Table 1 displays demographic information about the participants. 
Table 1

Demographic information about the study group

\begin{tabular}{cccc}
\hline Variable & Category & $f$ & $\%$ \\
\hline \multirow{3}{*}{ Gender } & Female & 100 & 67.57 \\
& Male & 48 & 32.43 \\
& Total & 148 & 100 \\
\hline \multirow{2}{*}{ Class } & Junior & 92 & 62.17 \\
& Senior & 56 & 37.83 \\
& Total & 148 & 100 \\
\hline
\end{tabular}

According to Table 1, the percentage of females in the study group was $67.57 \%$ while $32.43 \%$ of the participants were males. Additionally, $62.17 \%$ of the participants were junior students whereas $37.83 \%$ of them were senior students.

\subsection{Data Collection Process}

Data were collected by a semi-structured interview form. Interview form consisted of two parts; the first part included demographic information questions such as gender and class level and in the second part the participants were asked to complete 8 open-ended questions prepared by the researchers. To develop the interview form, firstly, the relevant literature was reviewed and a draft interview form was developed. Secondly, two experts who worked on Education Policy were consulted and one question was added to the form according to their recommendations. Then pilot interviews were conducted with one senior and one junior students from Education Faculty. After these interviews, some items were reorganized and expanded and then the interview form was finalized. The final semi-structured interview form consisted of 8 open-ended questions. Two examples of questions in the interview form are as follows:

$>$ Do you have any systematic problem in your primary or secondary education life?

$>$ What do you want to suggest as a solution to the policy makers?

Interview form also included informed consent which had information about the purpose of the research, brief information and contact information about the researchers, also, the statement that data would not be shared with third parties and would be used only for the purposes of the study. Before collecting data, ethical approval was provided from the University's Ethical Comitee with 2021/8 decision number. Data were collected online from the pre-service students attending the Education Faculty of a university in the central Anatolia region in Turkey during the spring semester of 2020-2021 academic year. The interview form was sent to the students via e-mail and the participants were asked to send it back to the researchers via e-mail after filling it out. It took the participants approximately 20 minutes to fill out the interview form.

\subsection{Data Analysis}

Each participant was given a code before the data were analyzed to provide anonymity. The content analysis method was used in the analysis of the data. The purpose of content analysis is to bring together and make sense within the framework of certain similar codes, categories and themes (Yildırım \& Şimşek, 2005). The cyclic process proposed by Saldaña (2009) for the qualitative data coding has been followed. In this first cycle the statements of the participants are directly translated into codes. In this coding cycle, the problems seen by the participants regarding the education system and the solution suggestions they offered for these problems were analyzed through the perceptions of the participants as much as possible. For example, if the participant talks about the student who studies just for exams, this data was given study for exam code. In the second cycle, the codes reached in this way were conveyed together in terms of similarities and categories were reached. For instance, all the codes such as study for exam and learn for exam were linked together in a category and named as exam-oriented education. In the third cycle, the themes have been reached by combining together the categories according to their similarities in terms of 
the meanings they express. For instance, all the categories concerning the knowledge at school such as theoretical knowledge and exam-oriented education were linked together and as a result, it became a theme namely, knowledge provided at schools. In this cycle, both the previously reached codes, categories and loops were reviewed and the findings were finalized.

\subsection{Validity and Reliability}

A number of measures were taken in order to increase the validity and reliability of this study. In order to endure the internal validity of the study: (i) while developing the questionnaire, a conceptual framework was formed by reviewing the relevant literature; (ii) open-ended questions and participants' opinions were taken into consideration as a whole and initial themes were formed accordingly. In order to ensure the external validity of the study, the parts of design, participants, data collection, data analysis and interpretation were described in detail. Reporting the collected data in detail, directly quoting the participants and explaining the results by using these quotations are among the important criteria of validity in a qualitativa research (Yıldırım \& Şimşek, 2005).

In order to ensure the internal reliability of the study: (i) the findings obtained from the data collected from the participants were presented directly without any comment, enriched with direct quotations, and the basis for later explanations and comments were formed; (ii) the study was conducted by two researchers, and at the stages of data collection, analysis and evaluation of the results, points of agreement were formed among the researchers, and this situation was considered as an issue that would increase the acceptance rate of the study for the readers. In order to ensure external reliability (i) all steps followed in the study were reported in detail and clearly; (ii) the raw data of the study have been preserved for possible future review.

\section{Findings}

According to the findings of the study, the problems of the Turkish education system and solutions suggested for these problems were classified under the following six themes as (i) knowledge provided at schools, (ii) students characteristics, (iii) teaching profession, (iv) physical environment (v), society's perception and (vi) implemented policies and these themes are presented in Table 2.

Table 2

Themes and categories

\begin{tabular}{ll}
\hline Themes & Categories \\
\hline \multirow{3}{*}{ Knowledge provided at schools } & exam-oriented education \\
& memorization \\
& limited educational environment \\
& theoretical knowledge \\
& not addressing students' interests and skills \\
& intense curriculum \\
& unquestioning \\
& academic achievement-oriented \\
Students characteristics & competitive \\
& suffering from psychological problems \\
& failing to discover himself \\
& hopeless \\
\hline Teaching profession & exam-based teacher employment process \\
& financial income \\
& lack of self-development \\
& insufficient physical environment \\
& non-functional physical environment \\
Physical environment & crowded classrooms \\
&
\end{tabular}


Table 2 continued

\begin{tabular}{ll}
\hline Themes & Categories \\
\hline Society's perception & the value that society gives to teachers \\
& perceptions about success \\
\hline & frequent changes \\
& lack of equal opportunities \\
& quality of universities \\
Implemented policies & quality of vocational high schools \\
& inadequate budget \\
\hline
\end{tabular}

\subsection{Problems Regarding Knowledge provided at Schools and Suggested Solutions}

According to the pre-service teachers, the main problem of the Turkish education system is "knowledge provided at schools". The categories under this theme are: (i) exam-oriented education, (ii) memorization, (iii) limited educational environment, (iv) theoretical knowledge, (v) not addressing students' interests and skills and (vi) intense curriculum (see Table 3).

Table 3

Problems regarding knowledge provided at schools

\begin{tabular}{ll}
\hline Theme & Categories \\
\hline & exam-oriented education \\
Knowledge provided at schools & memorization \\
& limited educational environment \\
& theoretical knowledge \\
& not addressing students' interests and skills \\
& intense curriculum
\end{tabular}

The participants reported exam-oriented education as the biggest problem related to knowledge provided at schools. Therefore, the primary goal of school has become solely to prepare students for the next level of education rather than providing them with knowledge they need. An examoriented education system encourages students to memorize. Students are supposed to take a 2-3 hour exam measuring the knowledge they have memorized for a specific period of time (3-4 years) so that they are accepted by schools at the upper level of education according to the scores they obtain from this high-stake exam, which is one of the most serious problems of this system according to the pre-service teachers. Moreover, students merely memorize the knowledge they need only for this exam; however, they do not digest this knowledge thoroughly. Providing only exam-specific knowledge at schools and students' studying only to pass the exams kill their enthusiasm about the learning process. As a result, students turn into individuals who memorize information, wait for an exam to trigger them to acquire information and confine knowledge only to school and exams. K83 explains this situation by noting a specific example "...When there were once discussions about excluding history course from the university entrance exam, some private educational institutions planned to exclude the history course from their curriculum and students stopped studying the history course for some time."

Learning has never been an enjoyable activity for students who memorize information or even wait for an exam to make memorization. K42 emphasized how learning is shaped by memorization and exam system as "Learning often made us feel as if we were eating tasteless snacks. It neither benefited our body nor brought us joy." Students now demand open high schools more when compared to the past due to the exam-oriented system. Indeed, students want to create more time for themselves to prepare for the university entrance exam by attending open high school. Therefore, it can be said that students even dropped out of schools to achieve their goals.

Another problem reported by the participants is to the presentation of knowledge at schools in a theoretical way without emphasizing practice. Students find it difficult to internalize the 
knowledge introduced in this way and fail to put it into practice in their daily lives. In addition to being theoretical and far from being practical, knowledge provided at schools is also nonfunctional since it cannot meet students' needs in today's world. In other words, knowledge learned at school is not useful for students. According to K59 "...some of the information we learn has no qualification other than that it only takes place in our minds". Another important problem related to knowledge provided at schools is that it is not relevant to students' interests and abilities, which encourages them to memorize and give up real learning. Even selecting their fields of study according to their interests and abilities in high schools is not a solution to this problem because they have to answer questions from other fields in the exam too. This situation was explained by $\mathrm{K} 7$ as follows:

Let's imagine two students studying to enroll the English Language Teaching department of a university. One of them answers 3 more mathematics questions than the other but has fewer number of correct answers in questions in the English Language section. The other has more correct answers in English Language section but fewer correct answers in the mathematics section. Maybe, the second student will be impressively successful in the department, have a perfect career, but he cannot enroll the department just because he has fewer correct answers in mathematics. Another [the former] student... enrolls the department since he answers questions from a totally irrelevant field. To me, this is completely unfair. Also, this situation can be explained by the fact that our education system is based on achievement scores rather than interest, talent and specialty area.

Finally, intense curriculum was voiced as another problem related to knowledge provided at schools. The participants stated that intense curriculum encourages students to memorize more and more and becomes an obstacle for learning.

The pre-service teachers suggested some solutions to minimize the problems related to knowledge provided at schools. Accordingly, the focus of education should be children's happiness; not their academic achievement. Among the solutions to achieve this focus are abolishing the exams and place students to upper level of education by taking into consideration the grades they obtain throughout this particular level of education as well as their interests and skills. Memorization, which occur due to academic achievement-oriented education, should be eliminated and students should be taught how to learn so that they can enjoy the learning experience and retain the knowledge they are provided with. It is also important to benefit from recent technologies while trying to implement these solutions. Because the participants believe that school education today does not appeal to students, who nowadays have a life dominated by technology. Another solution to ensure permanent learning is to allow students to choose their courses according to their interests and abilities. Intense curriculum and too much homework cause students to lose their enthusiasm when it comes to school. The participants suggested that enjoyable activities should be designed for children in parallel with the characteristics of their age rather than giving them homework so that they can love the school environment. Arts and sports can be used for this. Another strategy to make school an enjoyable place is to create a learning environment by taking individual differences into consideration in which children can learn by doing and experiencing according to their interests and abilities. For instance, it was recommended to do science courses by conducting experiments in the school environment and observations in nature. Finally, the pre-service teachers suggested designing a learning process encouraging students to learn and discuss topics instead of teachers' directly transferring knowledge to students.

\subsection{Problems Related to Student Characteristics and Suggested Solutions}

According to the participants, the second biggest problem of Turkish education system is student characteristics, which were classified under the following categories: (i) unquestioning, (ii) academic achievement-oriented, (iii) competitive, (iv) suffering from psychological problems, (v) failing to discover himself and (vi) hopeless (see Table 4). 
Table 4

Problems related to student characteristics

\begin{tabular}{ll}
\hline Theme & Categories \\
\hline & unquestioning \\
& academic achievement-oriented \\
Problems related to student & competitive \\
characteristics & suffering from psychological problems \\
& failing to discover himself \\
& hopeless \\
\hline
\end{tabular}

The participants believe that students of Turkish education system are unquestioning ones who do not think but accept everything as they are given. Moreover, students have to study for exams exceedingly that they do not have time to question the knowledge they receive and they get used to this situation in time. Some participants even claimed that an unquestioning generation is a deliberate policy. Indeed, the primary goal of each government is to protect and sustain its own ideology, have a strong economy, the presence of people who do not question, search, and criticize. Therefore, according to the participants education systems must educate individuals who are supposed to do whatever they are asked to.

Another prominent characteristic of students educated by the Turkish education system is that they are success-oriented and abandon their goal to behave ethically. Accordingly, the only criterion of success for students themselves is academic achievement while being a well-behaved person and meeting the expectations of society are no longer among the criteria of success. In other words, the participants believe that students with high level of academic achievement is "successful" even if they don't behave ethically. However, this situation is also becoming a serious problem in society according to the participants. The participant K64 explained these characteristics as follows:

We call students "successful and educated" only if they get high scores in the exams. However, this is success in teaching not in education. For instance, let's assume that a student enrolled the faculty of law, graduated from it-even as the top student- and started to work. If he accepts bribe in his job, or favor some people, can we consider this person as "educated"?

In addition, the participant believe that competitive students are another problem related to student characteristics. Students compete with their friends in order to get high scores from exams which provoke feelings of envy and competition. Similarly, K78 emphasizes the severity of the situation as follows: "Also, the feeling of competition imbued us through such exams. Even one finds it difficult to feel happy when his best friend managed to be accepted by a department because he himself failed to do so."

It is inevitable that that such a competitive environment is likely to have negative effects on students' psychology. Exams administered in a limited time cause stress and anxiety in students. According to the participants, everybody can feel stress in the modern life. However, when a teenager experiences stress, it becomes a heavy burden on student's psychology which results in depression and even a suicide attempt.

Students who find themselves in a constant competition in an exam-oriented education system cannot have enough free time to discover themselves, which is another serious problem of the system. Since they cannot discover their abilities and interests, deciding on their future profession becomes a big challenge for them. As a result, a student may choose the department of university which is irrelevant with his ability and interest. Finally, some students either drop-out or cannot find a job although they manage to graduate from this department.

The last category under this theme is students' lack of hope. Students lose their hopes for a better education system in the future since the system continuously changes, exams are getting more and more challenging and the number of educated unemployed people is increasing, which 
results in the emergence of a hopeless and carefree generation. K11 asked "if education is for students, why are students that much unhappy and hopeless?".

The pre-service teachers who participated in this study made some suggestions for the problems related to characteristics of students in the current education system. They believe that these students do not question but accept knowledge as it is presented. Thus, students should be encouraged to question. In addition to academic knowledge, they should be equipped with certain characteristics such as task awareness, national consciousness, and social values. To be specific, the primary goal of schools should be to make students behave ethically. One of the suggestions made is to educate students in terms of personality traits starting from earlier phases of education so that they can discover their interests and abilities, and their strengths and weaknesses; that is, they can know themselves. They can know and improve themselves only by doing the things mentioned above. Finally, it was recommended that school should employ more psychological counsellors and school counsellors so that students can easily overcome their psychological problems.

\subsection{Problems Regarding Teaching Profession and Suggested Solutions}

According to the participants, another problem of Turkish education system is related to teachers. There are three categories under this theme: (i) exam-based teacher employment process, (ii) financial income, and (iii) lack of self-development (see Table 5).

Table 5

Problems regarding teaching profession

\begin{tabular}{ll}
\hline Theme & Categories \\
\hline $\begin{array}{l}\text { Problems regarding teaching } \\
\text { profession }\end{array}$ & $\begin{array}{l}\text { exam-based teacher employment process } \\
\text { financial income } \\
\text { lack of self-development }\end{array}$ \\
\hline
\end{tabular}

The pre-service teachers think that selecting teachers to be employed in government schools with just one single exam (PPSE) does not effectively measure teacher candidates' knowledge about teaching. According to the results of this exam, teacher candidates who are likely to be successful in the teaching profession might be eliminated while those who are not likely to be a successful teacher might be employed in schools. Because PPSE measures only theoretical knowledge based on books, but it does not measure whether candidates have a suitable character or/and ability for teaching profession. K20 supported other participants' opinions that the exam system used in teacher selection process for employment is not sufficient:

For me, the most important and the main problem of our education system is the failure to select the most appropriate teachers for the teaching profession.... When we look at our system, we can easily see that teachers are selected [to be employed] according to academic achievement. However, to me, an academically successful teacher is beneficial only to himself. Knowing how to teach is as important as acquiring that knowledge...Teachers who imbue the next generation with the importance of peace, love, freedom and favor create our future. When I think all these, the source of all other problems in our education system and the most important problem for all of us is improper teachers.

Another significant problem related to selection of teachers for employment is that people prefer this profession for financial income and personal rights since it is possible to be a teacher by taking an exam measuring only academic knowledge. Those who pass this exam can become teachers no matter if they like this profession or not or if this profession is appropriate for their personality or not. This situation underlines that the teaching profession is no longer perceived as a profession that influences a child's life, guides a child for his future and introduces him to the world outside. Since teachers are the building stone of education, unqualified teachers will terribly affect children's education and future. 
Another problem related to teachers as stated by the participant is lack of self-development activities. Some students perceive the teaching profession as a simple public job since they do this job only for the salary. As a result, they are reluctant to improve themselves both in their field of teaching and general world knowledge and are not interested in scientific developments and art activities. In addition, especially relatively older teachers find it difficult to keep up with the changing system or technology, cannot improve themselves in necessary fields, which negatively affects their students' learning.

In short, the following issues were reported as problems related to teachers: since teachers are employed according to the scores obtained from an exam, those who can be very good teachers stay out of the system; individuals become teachers only to get a salary instead of choosing their professions according to their personalities and interests, and finally, teachers do not improve themselves. The participants provided some solutions to the problems related to the teaching profession. Firstly, PPSE should be revised in a way to measure certain teaching skills such as patience, communication, mentality and discipline. In addition to suggestions regarding this exam, the participants also suggested that teachers should continuously improve themselves by attending especially practical courses. They should read a lot about their field of teaching and improve their general world knowledge. Moreover, students should assess their teachers regularly so that teachers can see their weaknesses by analyzing the feedback from students and improve themselves by doing their best to overcome these weaknesses.

\subsection{Problems Related to Physical Environment of Education and Suggested Solutions}

According to the participants, there are three categories under the theme "physical environment of education": (i) insufficient physical environment, (ii) non-functional physical environment, (iii) crowded classrooms (see Table 6).

Table 6

Problems related to physical environment of education

\begin{tabular}{ll}
\hline Theme & Categories \\
\hline $\begin{array}{l}\text { Problems related to physical environment of } \\
\text { education }\end{array}$ & $\begin{array}{l}\text { insufficient physical environment } \\
\text { non-functional physical environment } \\
\text { crowded classrooms }\end{array}$ \\
\hline
\end{tabular}

They believe that schools are not suitable in terms of both infrastructure (building, electricity, water, the internet) and course materials. Some old school buildings need to be repaired or demolished because they threaten student's lives. Besides, some schools do not have any canteens which is necessary for students' nutrition. In addition, some schools cannot offer effective teaching in courses such as visual arts, science and technology due to inadequate equipment and materials although they have suitable infrastructure.

According to the participants, another serious problem is non-functionality of tools and equipment at schools. In other words, schools have tools and equipment; however, they do not have any positive effects on learning. Participants give examples of schools that are full of technological materials for keeping up with changes. However many teachers don't know how to use them which means these materials are useless. K74 who gave course books as an example to non-functional materials, clarified his opinions as follows:

...course books provided free of charge at the beginning of each semester... are not used by students and teachers effectively because they have inadequate content, there are many spelling mistakes, visuals that are not related to the topics are covered and the topics are explained by using unnecessary details. So what is happening to these course books? They are thrown into recycle boxes at the end of academic year. It is a pity that these course books tell how many trees are cut to have a sheet of paper. 
Finally, the participants reported that the last problem of Turkish education system in terms of physical environment is crowded classrooms. According to the participants the more crowded a classroom is, the less amount of personal communication occurs. When there is less amount of personal communication, certain problems arise such as lack of comprehension, not understanding the topic and boredom.

The most common suggestion made by the participant is to allocate more budget to improve the physical conditions of schools. In addition, it has been recommended that the government should leave education to private entrepreneurs instead of providing poor quality education. According to the participants, the problems of the Turkish education system are not limited to facilities of a school. Society's perception about education also affects and shapes education.

\subsection{Problems Regarding Society's Perception and Suggested Solutions}

According to the pre-service teachers, society's perception about education system is another problem of the Turkish education system. There are two categories under this theme: (i) the value that society gives to teachers and (ii) perceptions about success (see Table 7).

Table 7

Problems regarding society's perception

\begin{tabular}{ll}
\hline Theme & Categories \\
\hline $\begin{array}{l}\text { Problems regarding society's } \\
\text { perception }\end{array}$ & $\begin{array}{l}\text { the value that society gives to teachers } \\
\text { perceptions about success }\end{array}$ \\
\hline
\end{tabular}

Participants think that the value given to teachers has decreased when compared to the past. The departments of teaching used to be considered a challenging department and the teaching profession a highly prestigious one in the past. According to K27 “...nowadays it [teaching profession] has turned into a profession with no value at all and individuals now utter even the following words 'At least, you can be a teacher'". Since society in general do not value teachers, parents guide their children towards other professions which they find more prestigious. As a result, students who get relatively higher scores in the university entrance exam prefer other professions and those with lower scores have to prefer education faculties. This situation is considered an important problem of the education system. K86 explained his opinions about this issue as follows:

Necessary importance is not given for teacher education. Placing successful students in medicine faculties is important, so why shouldn't it be important for the teaching profession? Doctors must be successful because we place our life into their hands. Yes, it is necessary but we also tell teachers to create building stones of society. The significance of this mission cannot also be ignored.

According to the participants, society's perception about success is another problem of Turkish education system. The participants believed that what society considers "success" is only academic success and success in art is often ignored, which was explained by K16 as follows: "In addition, many parents has doubts about the intelligence of a student who is successful in art, music etc., but fails in mathematics, which is a serious problem itself."

According to the pre-service teachers, negative perceptions about the teaching profession should change. They suggested that teacher candidates should be administered more challenging exams and fairer job interviews so that qualified teachers can be employed in state schools. In addition, it has been suggested that the faculties that fail to provide quality education should be closed and the base score to be accepted by these faculties should increase. The participants believe that society's perception about teachers will be more positive as the quality of teachers increases. Another important problem is society's perception about success. People started to associate success with mathematics (or fields of science) due to the obligation to solve mathematics problems in the university exam even to be accepted by departments related to social sciences. Thus, the pre-service teachers suggested that a more clear-cut distinction should be made between 
fields. Another problem of the Turkish education system as reported by the participants is related to the implemented policies.

\subsection{Problems Related to Implemented Policies and Suggested Solutions}

According to the participants, another problem of the Turkish education system is implemented policies. There are five categories under this theme: (i) frequent changes, (ii) lack of equal opportunities, (iii) quality of universities, (iv) quality of vocational high schools and (v) inadequate budget (see Table 8 ).

Table 8

Problems related to implemented policies

\begin{tabular}{ll}
\hline Theme & Categories \\
\hline & frequent changes \\
lack of equal opportunities \\
Problems related to implemented policies & $\begin{array}{l}\text { quality of universities } \\
\text { quality of vocational high schools } \\
\text { inadequate budget }\end{array}$ \\
\hline
\end{tabular}

When the participants' statements about the problems of Turkish educations system are examined, we can see that the main problem is frequent changes in the system. Since the education system changes frequently, students, teachers and parents find it difficult to adapt themselves to these changes, which inevitably decreases the quality of education. Moreover, the participants think that the changes in the system have failed to provide permanent solutions to the problems in the field of education. K5 stated his thoughts as follows:

We are tussling with a system that has changed 15 times in 17 years; figuratively speaking, a system with loosened bolts due to hot plugging. 78 ministers of education since the declaration of the republic are also a strong proof for this situation (K5).

According to the participants, another problem related to the implemented policies is lack of equal opportunities in education. The participants focused on this lack of equal opportunities from different dimensions. The participants highlight the differences between private schools and state schools in terms of lack of equal opportunities. For instance, in private schools children attend art, music, sports or cultural activities in their free time; parents demand detailed information about the development of their children; parents can expect some revisions and regulations from the school administration; and teaching of foreign language education starts from early ages.

In addition, some participants emphasized the differences between schools in rural areas and urban areas. K2 explained the lack of equal opportunities between students attending these schools as follows: "Financial problems affect education of students living in rural areas. Thus, the possibilities of students living in urban areas are $80 \%$ more than those attending schools in urban areas."

Lastly, some participants highlighted lack of equal opportunities between male and female students. Turkish education system doesn't make enough contribution to women's education. According to the participants the reasons of the inequality between men and women are: the girls do not get education in some areas because they are forced to get married at early ages; some people want women just to be housewives; the educated women cannot have master's and PhD degree because they are often busy with housework; some parents think that girls should not attend a university in another city; in some areas there is a mentality "men are the breadwinner of a family".

According to the participants, another problem regarding the policies implemented in the Turkish education system is that the quality decreases with the increasing number of universities. They think that as the number of universities increases, students are accepted to universities by getting lower scores and graduate from these universities by receiving low quality education. This 
situation also affects education faculties. As the number of education faculties increases, students are accepted by these faculties despite their lower scores and graduate from education faculties which provide less quality education and start teaching. Thus, increasing number of universities decreases teachers' quality and, in turn, the quality of education in the country.

Not only the quality of universities but also of vocational high schools is also a problem according to the participants. Since the quality of vocational high schools are low, parents encourage their children to choose more prestigious schools. So, these schools have always had a secondary importance in public opinion. Finally, the participants think that inadequate budget is another problem of the Turkish education system. According to the participants, the government do not allocate enough budget for education. Many schools do not have sufficient material and infrastructure due to inadequate budget. Similarly, teachers cannot be employed despite the growing demand at schools due to the same problems.

The participants made some solution suggestions to the problems related to the implemented policies. The most common solution was that this frequently changing education should be adopted as a state policy rather than a government policy. Developing a national education system that is appropriate for Turkish culture is suggested as a solution to these frequent changes. In addition, the participants suggested that physical conditions of schools in urban areas and all government schools, which is considered a serious problem, should be improved to minimize inequality in terms of opportunities and possibilities by increasing the amount of budget allocated. In addition to budget increase, students suffering from financial problems, especially young female students, should be given non-repayable checks (funds) that can be used only for education expenses. Moreover, there should be at least one school in each village so that such an inequality can be minimized. Finally, the participant recommended that the quality of universities can be improved by decreasing the number of universities.

\section{Discussion and Conclusion}

In this study, the opinions of the pre-service teachers about the problems experienced in the Turkish education system and their solution suggestions were examined. The paradigm shift in education affect each stakeholder such as teachers, students, school administration and families which form the basis of Turkish education system. However, teachers might be considered as the most important element of the education system since they are primarily responsible for planning, implementing and assessing education-teaching activities. Therefore, the opinions of pre-service teachers, as teachers of the future, about the education system are essential since they provide information about to what extent these pre-service teachers know about the system, how sensitive they are against the problems encountered in the education system and their opinions based on their observations and experiences and their valuable suggestions to these problems. In this respect, the problems of the Turkish education system and solutions suggested to these problems by pre-service teachers in this study were classified under six themes according to the following categories: (i) knowledge provided at schools, (ii) student characteristics, (iii) teaching profession, (iv) physical environment (v), society's perception and (vi) implemented policies.

The pre-service teachers' opinions regarding the problems of Turkish education system often emphasized "knowledge provided at school" dimension. The problems observed in relation to this dimension are exam-oriented education, limited physical space, theoretical knowledge, not appealing to students' interests and skills and intense curriculum. According to pre-service teachers the main problem related to "knowledge provided at school" is exam-oriented education. Students use knowledge they receive without inquiring, questioning and criticizing so that they can pass to the next level, which forces them to memorize this knowledge. Similarly, Yilmaz and Altınkurt (2011), in their study, concluded that high-stake national exams and memorization-based education are the most problematic issues of Turkish education system. Exam-oriented and memorization-based education were a dimension determined in Taşdemir's study (2015) and Yeşil 
and Şahan (2015) dealt with this dimension as an education understanding and emphasized that changing education understanding cannot produce any solutions to current problems.

Another issue frequently voiced by the participants is that such a system is not appealing to students' interests and skills. Uluğ (1998) also pointed out that Turkish education system lacks potential to educate well-behaved and productive individuals who are aware of their own interests and abilities. Similarly, Kutlu-Abu et al. (2016) claimed that education system fails to discover and maintain children's interests and abilities. In addition, Özdemir and Kaplan (2017), in their study aiming to determine the problems of the education system, focused on failure to guide students according to their abilities, interests and needs as a professional guidance problem. According to pre-service teachers, the focus of education is not academic success, but the role of children in society as happy individuals. In this direction, the following solutions were suggested by the participants: removing high-stake national exams; placing students to one upper level educational institutions in line with their interests and abilities; eliminating the need for memorization by improving students' learning skills; and giving importance to fine arts and sports activities.

According to the study, the pre-service teachers think that the second important problem of Turkish education system is about student characteristics. They reported that the Turkish education system creates hopeless students who do not question, are achievement-oriented, suffer from psychological problems and fail to discover themselves. This situation can be considered an outcome of memorization-based education system, which is one of the biggest obstacles for real learning (Turan, 2006). Unlearned knowledge is almost impossible to retain and transfer to real life situations, which create passive students and discourage them to question, criticize and be creative (Taşdelen, 2012). Achievement-oriented approach is the natural consequence of exam-oriented education system. Başdemir (2012) dealt with academic education as one of the structural problems of Turkish education system. Similarly, Ural (2016) highlighted that our education system is excessively achievement-oriented and students cannot discover their interests and abilities in social, cultural and sport-related issues since they are often ignored in this system. Accordingly, the following suggestions are made to avoid this negative consequence: encouraging students to question, providing training to help them discover themselves, and employing more school psychological counsellors at schools.

Another problem mentioned by the participants is related to the teaching profession. Since teachers to be employed at state-run schools are selected according to the scores obtained from an exam, they see this profession only a source of income and they fail to improve themselves, which are perceived as a big problem by the participants. Taşgin and Sönmez (2013) examined the problems of the Turkish education system based on the opinions of teacher candidates through the news reflected in the media. The most frequently stated problem by the pre-service teachers in this study is related to the teaching profession. Yilmaz and Altınkurt (2011) reported some problems regarding teacher employment, which is also a problem linked to the teaching profession. In addition, Şener (2018) studied with a different sampling group and examined the opinions of actively working teachers in the Turkish education system regarding current problems. They found that teachers believe that teacher employment system and decreasing value of teaching profession are serious problems. Thus, it is possible to claim that pre-service and actively working teachers have similar opinions. As in all societies, the teaching profession has been adopted as an important value in our society from past to present and has always had a special position. In addition, it differs from other professions with its role of raising people (Bozbayındır, 2019; Karamustafaoğlu \& Özmen, 2004). However, it is stated that the teaching profession has been a more respected profession in our country until recently, and this value has been lost due to the exam and success-oriented education system (Turkish Education Social and Cultural Gene Association [TESCG], 2014). In this context, Symeonidis (2015) emphasized that in order to increase the status of the teaching profession, long-term and determined education policies should be established for teacher qualification. 
Another problem related to the teaching profession in the current study is teachers' failure to improve themselves. The participants reported that teachers were reluctant to improve themselves professionally once they start working and they see this profession as a source of income. Under the light of these findings, the most important solution suggested by pre-service teachers to the problems related to the teaching profession is to change teacher selection and employment procedures. In addition, it is suggested that teachers should continue to improve themselves professionally.

The participant pre-service teachers, who highlighted that schools are not suitable for learning in terms of infrastructure and material, listed the problems related to the physical environment of education as "inadequacy and non-functionality of physical environment" and "crowded classrooms". Şişman (2019) claimed that the education system has problems related to infrastructure, technology and hardware and the inadequacies in terms of physical and technological infrastructure still exist. In addition, inadequacies in terms of physical and technological infrastructure and crowded classrooms were also reported as problems in other studies too (Gelbal \& Kelecioğlu, 2007; Yolcu \& Kartal, 2010; Yılmaz \& Altınkurt, 2011). Çetin et al. (2018) highlighted lack of course materials in addition to inadequate physical and technological infrastructure. Aydin (2017) pointed out that appropriate physical environment is an indispensable component of effective learning and teaching process and physical variables might affect teacherstudent interaction in the classroom. In this sense, the existing problems related to physical environment in the education system have the potential to affect the quality of education-teaching services. Among the solutions suggested by the pre-service teachers related to physical environment, allocating higher budget to improve physical conditions of schools stands out

The perception of society about the education system was also perceived as a problem in the current study. The pre-service teachers pointed out that the teaching profession is valued less and parents guide their children to other professions which they think are more valuable and rewarding. In parallel with the findings of this study, Özyılmaz (2013) also found that the teaching profession has lost its appeal in people's eyes. The reasons lying behind this finding might be low salary, inadequate personnel rights and negative opinions expressed by politicians (Bozbayindir, 2019). The participants of this study suggested that this negative perception of society about the teaching profession should change. Among the solutions suggested pre-service teachers are employing teachers by administering more challenging exams and more fair job interviews for candidate teachers, closing education faculties that fail to provide unqualified education and increasing the exam score required to be accepted by education faculties.

According to the pre-service teachers, another problem of the Turkish education system is about the policies implemented. Frequent changes in the system, lack of equal opportunities, low quality of universities and vocational high schools and inadequate budget are the problematic areas in the field. The participants emphasized the problems related to policies employed in the Turkish education system. Frequently changing system affect all shareholders including students, teachers, school administrations and parents in different ways. We should keep in mind that any problem in any field of the education system and changes to be made to solve this problem have the potential to affect all components of the system (Neyişci et al., 2020). Failure to maintain continuity in the education system and frequent changes are among the most common problems voiced by pre-service teachers (Özdemir \& Kaplan, 2017; Yeşil \& Şahan, 2015). Another study conducted with school administrators concluded that frequent changes is the most pressing problem in the Turkish education system (Karakütük \& Özdoğan-Özbal, 2019). Feeling of uncertainty due to frequent changes in the system causes lack of confidence and adaptation problems (Kara, 2020). Therefore, Yaşar and Sözbilir (2017) suggested that it is essential to conduct infrastructure studies before implementing some changes, to make changes and innovations that are suitable for the requirements of modern area and to avoid doing too many changes in the education system. 
According to the participants, another problem related to the policies implemented in Turkish education system is lack of equal opportunities. Gedikoğlu (2005), in his study, emphasized lack of equal opportunities as a problem of the education system. Similarly, Kutlu-Abu et al. (2016) found that inequality in accessing educational activities is a problematic area in the system. Çetin et al. (2018) asserted that the participants perceived exam system, teacher qualities and inadequate equipment as important problems in addition to inequal education opportunities. Equal opportunities and facilities are one of the fundamental principles stated in Basic Law of National Education numbered 1739, which is one of the most important foundation of Turkish national education system. Equal opportunities and facilities guarantee that each individual - male or women- are provided equal opportunities and facilities. However, lack of equal opportunities and facilities are considered one of the most important problems of the education system. When individuals benefit from education opportunities equally, this situation positively affects their academic achievement. Therefore, it is essential to implement different education policies to improve equality in education.

This study examined pre-service teachers' opinions regarding the problems in the Turkish education system in detail and reported solution suggestions for many problems. Globalization necessitates some changes and transformations in education just like in other fields. Therefore, some changes might be implemented to educate individuals who can adapt to the changing requirements of modern age; however, some problems and deficiencies are observed as well. Thus, it is crucial to solve the existing problems and overcome deficiencies so that education can effectively fulfill its basic functions and achieve its goals. In addition to aiming to help students develop emotional transformations such as empathetic awareness, sensitivity, compassion, aesthetics and kindness, education has valuable contributions to different aspects such as educating qualified individuals, productivity, creativity, social justice and peace, scientific and technological development, innovation and fair distribution of income (Aydin, 2014, 2015). All these issues should be taken into consideration while structuring the Turkish education system; and all changes to be implemented in the system should be evaluated with a holistic perspective. In this context, it can be ensured that stakeholders such as teachers, students, school administrators and families participate in the decision-making process in any changes to be made regarding the education system. In addition, it may be beneficial to include the trial process before the changes to be made and to revise the implementation according to the feedback in this process. Finally, the success of an education system will only be possible with the training of qualified teachers. In this direction, regulations should be made to implement educational policies that will appeal to all areas of development such as communication and psychological well-being as well as professional development of teachers.

\section{References}

Açıkgenç, A. (2009, March). Küreselleşme karşısında yeni bir eğitim felsefesine doğru [Towards a new educational philosophy in the face of globalization]. Paper presented at the International Congress on Philosophy of Education. Ankara.

Aydın. A. (2014). Eğitim hikayedir [Education is a story]. Pegem Akademi.

Aydın. A. (2015). Eğitim politikası [Educational policy]. Pegem Akademi.

Aydın, A. (2017). Sinıf yönetimi [Classroom management]. Pegem Akademi.

Başdemir, H. Y. (2012). Türk eğitim sisteminin yapısal sorunları ve bir öneri [Structural problems of the Turkish education system and a suggestion]. Journal of Liberal Thought, 67, 35-52.

Bozbayındır, F. (2019). Investigation of teachers' views in the basis of the factors affecting the status of teaching profession. Electronic Journal of Social Sciences, 18(72), 2076-2104. http://dx.doi.org/10.17755/esosder.583274

Çetin, H., Yazar, M. I., Aydın, S., \& Yazıcı, N. (2018). Primary mathematics teacher candidates' views on the problems of Turkish education system and solution proposals. Mediterranean Journal of Educational Research, 12(25), 117-135. 
Demir, E. (2017). Analysis of middle school $6^{\text {th }}, 7^{\text {th }}$ and $8^{\text {th }}$ grade Turkish class teacher's guidebooks in terms of interdisciplinary approach. Electronic Turkish Studies, 12(25), 237-252. http://dx.doi.org/10.7827/TurkishStudies.12192

Demirtaş, H., Üstüner, M., \& Özer, N. (2007). Examining school management problems by student and school related variables. Educational Administration: Theory and Practice, 51, 421-455.

Ergün, M. (2018). Modern eğitim sistemlerinin doğuşu ve gelişimi [The birth and development of modern education systems]. Pegem Akademi.

Gedikoğlu, T. (2005). Turkish education system in the process of European Community: Problems and solutions. Mersin University Journal of the Faculty of Education, 1(1), 66-80.

Gelbal, S. \& Kelecioğlu, H. (2007). Teachers' proficiency perceptions of about the measurement and evaluation techniques and the problems they confront. Hacettepe University Journal of Education, 33, 135145.

Gül, H. (2008). Türkiye'nin eğitim sorunları, AKP'nin eğitime bakışı ve çözüm önerileri [Turkey's education problems, AKP's perspective on education and solution proposals]. Toplum ve Demokrasi, 2(3), 181-196.

Gür, B. S. \& Çelik, Z. (2009). Türkiye'de millî eğitim sistemi: Yapısal sorunlar ve öneriler [National education system in Turkey: Structural problems and suggestions]. Seta Vakfı.

Kara, M. (2020). The problems of Turkish education system according to the opinions of stakeholders in education. Journal of Kirsehir Education Faculty, 21(3), 1650-1694.

Karakütük, K. \& Özdoğan-Özbal, E. (2019). Problems, problem solving techniques of educational administrators. Journal of National Education, 48(223), 33-60.

Karamustafaoğlu, O. \& Özmen, H. (2004). An investigation of the value of teaching profession among teacher-candidates and Turkish society. Journal of Values Education, 2(6), 34-49.

Karip, E. \& Köksal, K. (1996). Etkili eğitim sistemlerinin geliştirilmesi [Developing effective education systems]. Educational Administration: Theory and Practice, 6(6), 245-257.

Kartal, S. (2013). The points to change by candidate teachers perceptions about our education system. Uşak University Journal of Social Sciences, Special issue, 248-262. http://dx.doi.org/10.12780/UUSBD185

Kaya, H. (2008). The secondary education in Austria and a comparison between Turkey in terms of geography education [Unpublished master thesis]. Marmara University, Istanbul.

Kösterelioğlu, İ. \& Bayar, A. (2014). An assessment of recent issues of Turkish education system. The Journal of Academic Social Science Studies, 25(1), 177-187. http://dx.doi.org/10.9761/JASSS2279

Kutlu Abu, N., Bacanak, A., \& Gökdere, M. (2016). Prospective teachers' views about the problems of Turkish educational system. Amasya Education Journal, 5(1), 287-307.

Merriam, S. B. (2009). Qualitative research: A guide to design and implementation. San Francisco, CA: Jossey-Bass.

Neyişci, N., Turabik, T., Gün, F., \& Kısa, N. (2020). Problems of the Turkish education system according to the prospective teachers and their possible solutions. Kastamonu Education Journal, 28(6), 2257-2270. http://dx.doi.org/10.24106/kefdergi.4095

Örücü, D. (2014). Pre-service teachers' metaphors towards school, school administrators and Turkish education system. Educational Administration: Theory and Practice, 20(3), 327-358.

Özdemir, A. \& Topal, M. (2019). Evaluation of the problems of Turkish education system by using DEMATEL and analytic network process methods. Marmara University Atatürk Education Faculty Journal of Educational Sciences, 50(50), 160-184.

Özdemir, F. \& Kaplan, A. (2017). Problems of Turkish education system and solution proposals for these problems according to the perspective of prospective teachers. Electronic Turkish Studies, 12(28), 577-592. http://dx.doi.org/10.7827/TurkishStudies

Özyılmaz, Ö. (2013). Türk milli eğitim sisteminin sorunlar ve çözüm arayışları [The problems of the Turkish national education system and the search for solutions]. Pegem Akademi.

Patton, M. Q. (2002). Qualitative research \& evaluation methods. Thousand Oaks.

Saldaña, J. (2009). The coding manual for qualitative researchers. Sage.

Symeonidis, V. (2015). The status of teachers and the teaching profession: A study of education unions' perspectives. Education International Research Institute.

Şener, G. (2018). A current overview of education problems in Turkey. Journal of National Education, 218, 187199.

Şişman, M. (2011). Eğitime giriş [Introduction to education]. Pegem Akademi.

Şişman, M. (2019). Türk eğitim sistemi ve okul yönetimi [Turkish education system and school management]. Pegem Akademi. 
Taşdelen, V. (2012, June). Eğitimde ezberleme ve anlama [Memoration and comprehension in education]. [Paper presented at Van Province Education Problems Workshop. Yüzüncü Y1l University, Van.

Taşdemir, M. (2015). Problems perceived by preservice teachers on the Turkish national education system. Electronic Turkish Studies, 10(7), 881-897. http:// dx.doi.org/10.7827/TurkishStudies.7898

Taşgın, A. \& Sönmez, S. (2013). Assessment of general teacher proficiencies according to the views of classroom teachers and pre-service classroom teachers. Middle Eastern $\mathcal{E}$ African Journal of Educational Research. 3, 80-90.

Turan, İ. (2006). The levels in the geographical concepts of primary school teacher programmes students and memorization without comprehension. Journal of National Education, 170, 274-292.

Turkish Education Social and Cultural Gene Association [TESCG]. (2014). Öğretmen gözüyle öğretmenlik mesleği [Teaching profession from the perspective of the teacher]. Turkish Education Association.

Turkish Language Association (n.d.). Güncel Türkçe sözlük [Daily Turkish dictionary]. https://sozluk.gov.tr/

Uluğ, F. (1998). Eğitim sisteminde değişme yapısal uyum sorunları [Structural compatibility problems to change in the education system]. Educational Administration: Theory and Practice, 4(14), 153- 156.

Ural, A. (2016). Yarışmacı eğitim anlayışının etkileri üzerine bir çözümleme [An analysis on the effects of competitive education]. Journal of Critical Pedagogy, 43, 19-24.

Yaşar, M. D. \& Sözbilir, M. (2017). Prospective science teachers' views related to the Turkish education system: Current problems and proposed solutions. Cukurova University Faculty of Education Journal, 46(1), 165-201.

Yeşil, R. \& Şahan, E. (2015). Perceptions of teacher candidates about the most important problem of Turkish education system, its reason and its solutions. Journal of Kirsehir Education Faculty, 16(3), 123-143.

Yıldırım, A. \& Şimşek, H. (2006). Nitel araştırma yöntemleri [Qualitative research methods]. Seçkin.

Yilmaz, K. \& Altınkurt, Y. (2011). Prospective teachers' views about the problems of Turkish educational system. International Journal of Human Sciences, 8(1), 942-973.

Yolcu, H. \& Kartal, S. (2010, May). Eğitim fakültesi son sinıf öğrencilerinin görüşlerine göre Türkiye eğitim sistemine ilişkin yaşanılan sorunlar [The problems encountered regarding the education system in Turkey according to the views of senior students of faculties of education]. Paper presentated at the 9th National Primary Education Symposium. Elazı $\breve{g}$, Turkey. 